Dark Cities? Developing a methodology for researching dark tourism in European cities

\author{
Powell, R. \& Kennell, J., University of Greenwich, UK.
}

\begin{abstract}
Despite the recent growth of research into dark tourism (Dale \& Robinson, 2011; Lennon \& Foley, 2000; Stone, 2013; Tarlow, 2005) and the growth of the dark tourism market (Biran \& Hyde, 2013; Stone 2005; Stone \& Sharpley, 2008), there has been little interest shown in understanding the relationship between dark tourism and urban tourism (Page \& Hall 2002). This paper presents the initial findings of a research project that investigates the dark tourism products offered by European cities. A series of keywords were developed following a review of the dark tourism literature and this was used carry out a content analysis of the Destination Marketing Organisation websites for Europe's ten most visited cities. The content analysis used Stone's (2006) Dark Tourism Continuum to evaluate the dark tourism products offered in each destination and to present a descriptive overview of Europe's citybased dark tourism offer. The paper concludes that there are a wide range of dark tourism products available to urban tourists in Europe, but that these are rarely conceptualised as such. The mixture of 'light' and 'dark' dark tourism products presents difficulties in categorisation and standardisation of the urban tourism offer, but this is a potential area of new product development for DMOs across Europe.
\end{abstract}

\title{
Introduction
}

The academic study of dark tourism gathered momentum in the early twenty-first century, and is reflecting the growing interest of the citizens of postmodern societies in the sites of death and disasters - an interest that needs deeper research to be understood fully. It also reflects the increased sensitivity of the international community to the significance of such events for nations, national identities and the direction of their history. Dark tourism sites offer the opportunity to capture and conserve the "dark" memory of humanity and make it available, through domestic and international tourism, to the wider public. It should also be 
noted that vicarious thrill seeking and entertainment motivations are also significant factors that have affected the recent growth of the dark tourism sector. This study of dark tourism in an urban setting, therefore, offers the opportunity to investigate the many ways in which dark tourism offerings are packaged and presented as tourism products within a significant sector of the tourism industry.

\section{Dark Tourism}

Dark tourism can be defined as tourism associated with the visitation of sites which have death, tragedy or suffering as their main theme. Commonly such visits are conducted with commemoration, education or entertainment in mind (Stone, 2005). Europe has an abundance of such sites, both real and imagined which offer ample opportunities to experience dark tourism in all of these ways if so desired. However, they are rarely conceptualised as dark products, and as such categorisation of individual attractions is, at the moment, confused.

A much observed trend in modern tourism is that tourists are increasingly moving towards niche or specialist holidays. The days of the $3 s^{\prime} s$ (sun, sea, sand) mass tourism package holidays are not yet over, but there are an increasing number of viable options open to both the more adventurous tourist as well as those looking for a more homogenised and prepackaged experience. Lennon and Foley (2000) have largely been credited with coining the phrase "dark tourism" in "Dark Tourism: The Attraction of Death and Disaster" They sought to signify what they identified as a "fundamental shift in the way in which death, disaster and atrocity are being handled by those who offer associated tourism 'products' "(p3). In doing so, they identified that dark tourism as it is presented in a modern context is the product of the late modern world, and is intimately connected to the political, sociological, economic and technological landscape within which modern tourism products are made available. That is to say, whilst death and disaster have always had a universal appeal, the circumstances of modern media, accessibility and technology mean that interest in dark sites is at an unprecedented level, and the tourism industry should be capable of making every effort to provide a product which meets the demand for such dark experiences. The 
increasing consumerism of post-modern western societies has a tendency towards making such experiences much more entertainment based.

The concept of dark tourism however is not a new one. Tourists have been drawn to battlefield sites, places of execution, tombs and other related sites for a very long time (Stone, 2005). Seaton (1996) has identified dark tourism as being the visitation of sites associated with death and disaster, something which dates from the Middle Ages at least. Dale and Robinson (2011) also identify Dark Tourism as being an established practice as far back as the Eleventh Century. It is possible to argue that dark tourism as an actuality was established in ancient times: a compelling thought if we consider the popularity of Roman Gladiatorial contests for example.

Historically it can be seen that tourism has always had aspects of dark tourism in its gaze. Several commentators (Lickorish and Jenkins, 1997; as cited in Lennon and Foley, 2000; Vellas and Becherel, 1995) have identified that pilgrimage is one of the earliest forms of tourism. Pilgrimage sites are often associated with death in one form or another, with religious pilgrims often visiting the site of the death, or the graves of individuals or groups. Such visits tend to have religious or spiritual associations relevant to the pilgrims visiting, and are seen as acts of remembrance, commemoration or veneration, and usually feature as part of a ritualistic or tokenistic ceremony, perhaps tied to a particular religious or even secular calendar. It is clear that such ritualistic approaches to commemoration are not solely the stuff of sanitised tourism products within the remit of the modern tourism industry. It should be recognised that there is an increasing demand for dark tourism products which offer a connection with scenes of suffering and death. That is not to say that this is a completely modern phenomenon: visitation to scenes associated with death in particular; battlefields, graveyards and the former homes of dead celebrities for example, have proven to be a significant motivator in tourism in past-times as well. However, of particular significance to this study is the consideration of the commodification of such sites has transformed the tourism industry in such a way as to generate demand for, as well as access to, dark tourism experiences. 
The attraction of death, disaster and the macabre promises to be a significant factor in the tourism sector worldwide, and in Europe in particular. Dark tourism, or thanotourism as it is sometimes called, offers the interested participant the chance to "gaze upon real or recreated death" (Stone, 2005: 3.) The fascination with scenes of tragedy is not unique to any one set or group of tourists, but dark tourism, as yet, remains on the fringes of respectability: a number of authors have given consideration to "shades" of dark tourism (Lennon and Foley, 2000; Stone, 2005; Strange and Kempa, 2003) which is to say that it is recognised that there is a continuum of "dark" touristic experiences, ranging from very mild excitation to the grim reality of the holocaust and terrorism, for example.

Stone (2005) considers dark tourism to be an old concept in a new world. That is to say that the fascination with scenes of death and disaster are old and quite possibly universal, but what is new is the way in which there is a commercialised and functional tourism industry able to make very much more available to very many more people than was the case in the past. The definition of dark tourism is wide and varied. Smith (1998) argues that sites associated with war probably attract more visitors than any other single type of attraction. Dark tourism is a widespread and growing reality and it is an important factor when considering the supply and demand of sites and attractions.

The motivations for visiting dark sites is an under-researched area (Sharpley and Stone, 2009), and somewhat beyond the remit of this paper. However, Stone (2005) identifies that the desire to create a mercantile advantage or manipulate a particular site for political reasons are usually the primary supply-side factors which will determine whether a Dark site is developed or not. It should also be noted that a usual explanation for the establishment of Dark sites is that they allow contemplation of one's own death - the memento mori effect (Walter, 2006). Inauthentic offerings allow this contemplation to be at several stages removed, unlike the horror of a death camp for example. There is also a marked reluctance to be seen to be making money from other people's suffering, and it may be that esoteric questions of taste cloud the development of more authentic dark sites.

It is often observed in the literature that dark tourism has a continuum of darkness (see fig 1 below). At the darkest end of that continuum, attractions are categorised largely on the 
basis of real, recent and actual suffering and death. There is often an educational and commemorative rationale which underpins the establishment of an attraction, very often being the authentic site of the suffering which is visited, such as at Auschwitz or the site of the Twin Towers in New York.

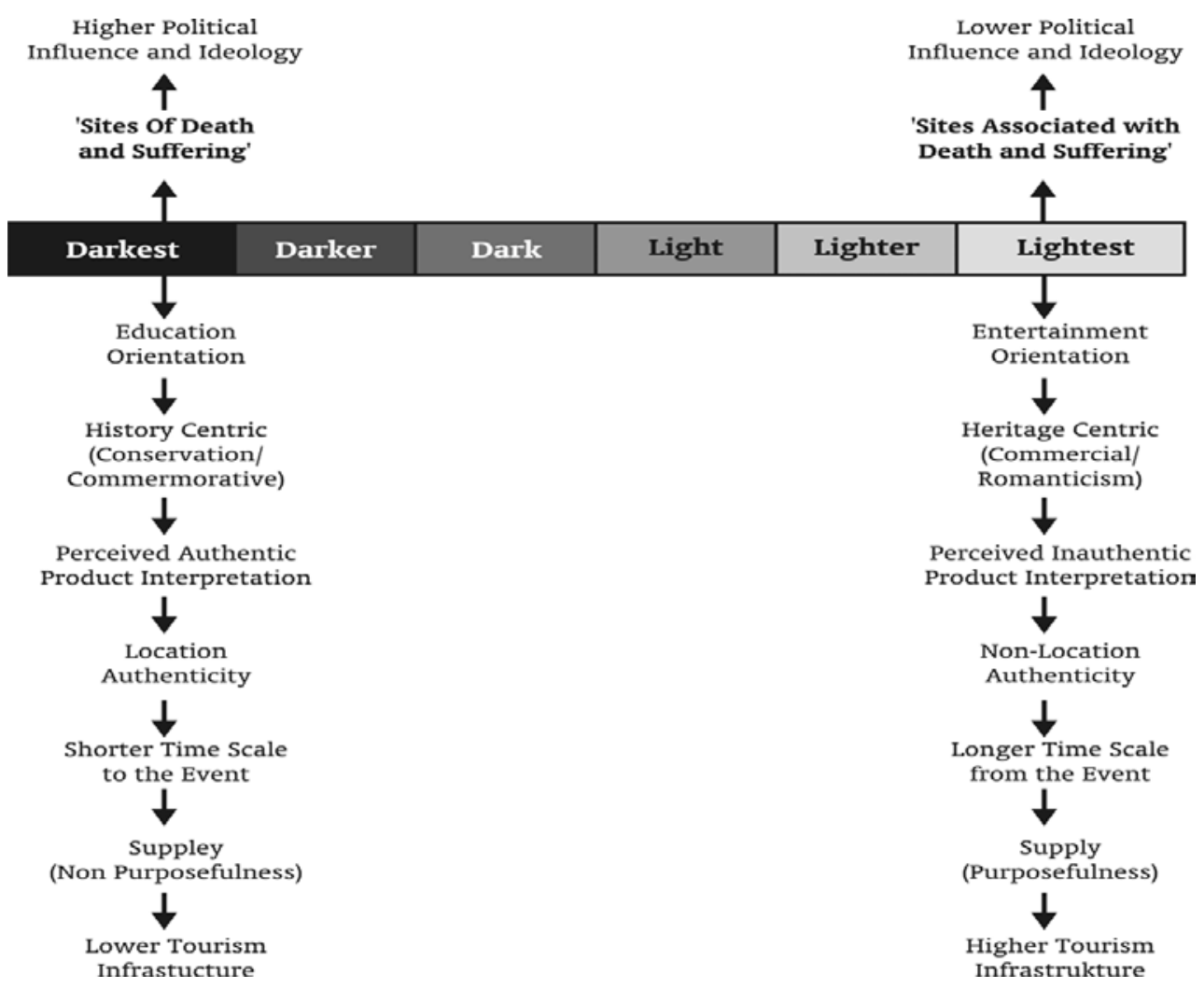

Figure 1 - A Dark Tourism spectrum: perceived product features of Dark Tourism within a "darkest-lightest" framework of supply (Stone, 2006)

Stone (2006) recognises that the connection with Dark Tourism at particular sites is fluid, and the relative darkness of each attraction lies along a continuum, ranging from the very dark (Auschwitz, for example) to the commodified, entertainment based attraction, such as the London dungeon which represents gruesome torture as family entertainment. Stone's continuum is the basis on which attractions in Europe will be referenced for the purposes of this study.

\section{Urban Tourism in Europe}


Urban tourism is a challenging and multi-disciplinary field of study that draws on areas including sociology, urban studies, planning and architecture, as well as traditional tourism research (Selby 2004). Research in urban tourism has been prompted by the recent dramatic growth of tourism to cities. Urry (2002) noted that the shift of tourism to urban areas from traditional coastal destinations has accompanied a broader shift within postmodern culture, which prioritises consumption, accessibility, culture and technology, which began in the 1980s. Gale presents Urry's (1994) set of processes that exemplify the postmodern transformation of culture, and therefore tourism. These are based on Harvey's (1989: 340-341) categorisations

- Clock time to instantaneous time

- Writing and substance to image and surface meaning

- Occupation and home to consumption and play

- Fordism to post-Fordism

- Globalization to Localization (Gale 2005: 92-93)

Some implications of this are highlighted:

- Overseas travel (image, status) becomes more desirable

- Overseas travel becomes easier and more affordable due to time-space compression

- 'post-tourists' or 'post-modern tourists' didn't like the regimented Saturday to Saturday element of traditional holidays (Gale 2005: 94)

- The weakening of group identities and associations affects places designed to service these groupings and offer an alternative to an older form of the collective holiday experience.

- The importance of fashion and taste - older resorts become 'tasteless' (Gale 2005: 93)

By the end of the 1990s, many post-industrial cities were seeking ways of diversifying their economies, and tourism development offered opportunities for investment and promotion (Ben Dalia et al 2013). Hoffman (2003) studies the development of Harlem, New York in the post-Fordist period from the perspective of regulation theory and shows how significant 
changes in the local economy over a period of thirty years have provided specific opportunities for tourism development in the area. For example, cultural diversity has become a key aspect of marketing in a highly differentiated market place and the area of Harlem can offer products and services that meet the needs of many different cultural segments, as well as the desires of tourists to consume diverse products, leading to a growth in niche tourism products such as cultural tourism which are an example of 'flexible specialisation', a concern of regulationist approaches to understanding post-Fordist economies. Whilst noting that tourism appears to function well as an economic engine for urban areas, Gladstone \& Feinstein note that 'the distributional consequences of tourism are more debatable' (2001: 38).

Urban tourism offers a number of benefits to destinations. Unlike other forms of tourism, it displays little seasonality (Higham \& Luck 2010), attracts relatively well educated and welloff tourists and provides opportunities for niche tourism development such as business tourism (Davidson 1996) and cultural tourism (Richards 2007). Urban tourism is now a core part of urban redevelopment and competitiveness strategies (Richards \& Wilson 2007, Spirou 2007, Smith 2007b, Zukin 1995), but this only serves to reinforce the already central role of tourism and culture in the development and image of urban areas. As Sharon Zukin points out, "For several hundred years, visual representations of cities have 'sold' urban growth. Images, from early maps to picture postcards, have not simply reflected real city spaces; instead they have been imaginative reconstructions - from specific points of view of a city's monumentality" (1995: 16). The huge competition between cities, coupled with the growth in accessible transportation and the emergence of new economies into the global economy, has meant that cities that have not historically been well-known tourism destination to enter the tourism industry, leading to increased global completion between cities for urban tourists (Ben Dalia et al 2013). Because of this, it is important for cities to understand areas of the tourism market in which they can offer novel and unique experiences to tourists, to increase their attractiveness - The growing Dark Tourism market (Biran \& Hyde, 2013; Stone 2005; Stone \& Sharpley, 2008) offers a way for many cities to become more competitive in this sense. 
If we define urban tourism simply as tourism that takes place in urban areas, it becomes more important to develop a thorough understanding of the components of urban tourism destinations. Selby (2004), in his review of previous writing on urban destinations, includes the following aspects of cities as forming part of the foci of urban tourism research: historic cities, casinos, urban regeneration, major sporting events, visitor management, historic districts, entertainment districts, tourist zones and sacred spaces. Van den Berg et al (1995) describe the five aspects of what they call a 'tourist city'. Firstly, primary products. These are the core reasons why tourists visit a city and can include natural features, historical attributes and specialist tourism facilities such as conference venues, sporting arenas and museums. Next are the secondary products and services, such as accommodation, retail, restaurants and information, which are necessary for generating staying visits, as opposed to day visits in a city. External transport is the third aspect of the tourist city, highlighting the connectivity of the city to tourism-generating regions. The fourth aspect is internal transport: the city must be easily navigable to tourists to ensure that the whole city becomes a resource to tourism, again extending the length of visits. Finally, the tourist city must have a developed tourism image. The image of the city is developed from the relationship of the first four elements to the marketing activates of the city's Destination Management Organisation and the perception of the city held by potential visitors.

An argument of this paper is that dark tourism products form a core part of many cities' tourism offer and that this has not been captured to date in the literature on urban tourism. In terms of Van den Berg et al's description of the tourist city, this paper aims to explore the possibility of dark tourism as a primary product for European cities, with implications for the marketing activities of Destination Management Organisations in the region.

\section{Methodology}

This paper presents the initial findings of an exploratory research project that has the aim of understanding the significance of dark tourism in the tourism offer of European cities. It follows on from research by Powell \& lankova (2015) which explored the nature of London's dark tourism offer. The current research will be used to identify a series of case studies of dark tourism in European cities for further research over the next three years. 
This initial, exploratory research, was carried out using a content analysis methodology. Content analysis is a method of qualitative data analysis (QDA) that involves "careful, detailed, systematic examination and interpretation of a particular body of material to identify patterns, themes, biases and meanings" (Berg 2007: 304). This method of QDA contains elements of a more quantitative approach as it typically involves a systematic unitising of textual data, amongst which the researcher will look for relationships; frequently the results of this method will be presented numerically or analysed using statistical techniques. However, Berg (2007: 308) points out that to think of content analysis as a quantitative procedure is to concentrate too heavily on the process of data manipulation and to under-represent the process of analysis of the data which "involves developing ideas about the information found in the various categories, patterns that are emerging, and meanings that seemed to be conveyed. In turn, this analysis should be related to the literature and broader concerns and to the original research questions." Approaching content analysis in this way brings it in line with interpretive QDA methods and this is the approach taken to content analysis in this research.

For this exploratory research, a purposeful sample (Bryman \& Bell 2009) was constructed to allow for the collection of an initial set of data on European cities and Dark Tourism. An extreme case (Saunders et al 2007) approach was taken to choosing which cities were included in the sample to increase the likelihood that the chosen cities would provide sufficient data on their tourism products to support this initial phase of research. Using the most recently published Euro monitor data for international tourism arrivals (Euromonitor 2014), the following list of the top ten European tourist cities was constructed as the sampling frame for this research.

Table 1 - top European tourist cities

\begin{tabular}{|l|l|l|l|}
\hline City & $\begin{array}{l}\text { International } \\
\text { Arrivals }\end{array}$ & $\begin{array}{l}\text { Destination } \\
\text { Management } \\
\text { Organisation }\end{array}$ & Website (English version) \\
\hline London, UK & $16.8 \mathrm{~m}$ & Visit London & http://www.visitlondon.com/ \\
\hline
\end{tabular}




\begin{tabular}{|c|c|c|c|}
\hline Paris, France & $15.2 \mathrm{~m}$ & Paris Info & http://en.parisinfo.com/ \\
\hline Rome, Italy & $8.68 \mathrm{~m}$ & $\begin{array}{l}\text { Rome Official } \\
\text { Tourist Site }\end{array}$ & http://www.turismoroma.it/?lang=en \\
\hline $\begin{array}{l}\text { Prague, } \\
\text { Czech } \\
\text { Republic }\end{array}$ & $6.20 \mathrm{~m}$ & Prague.eu & http://www.prague.eu/en \\
\hline Milan, Italy & $5.8 \mathrm{~m}$ & Visitamilano & http://www.visitamilano.it/turismo_en/ \\
\hline $\begin{array}{l}\text { Barcelona, } \\
\text { Spain }\end{array}$ & $5.52 \mathrm{~m}$ & $\begin{array}{l}\text { Barcelona } \\
\text { Turisme }\end{array}$ & http://www.turismedebarcelona.net/ \\
\hline $\begin{array}{l}\text { Amsterdam, } \\
\text { Netherlands }\end{array}$ & $5.20 \mathrm{~m}$ & $\begin{array}{l}\text { I am } \\
\text { Amsterdam }\end{array}$ & http://www.iamsterdam.com/en/visiting \\
\hline $\begin{array}{l}\text { Vienna, } \\
\text { Austria }\end{array}$ & $5.18 \mathrm{~m}$ & $\begin{array}{l}\text { Welcome to } \\
\text { Vienna }\end{array}$ & http://www.wien.info/en \\
\hline Venice, Italy & $5.16 \mathrm{~m}$ & $\begin{array}{l}\text { Venice } \\
\text { tourism }\end{array}$ & $\begin{array}{l}\text { http://www.venice- } \\
\text { tourism.com/en/visit-venice.html }\end{array}$ \\
\hline $\begin{array}{l}\text { Sofia, } \\
\text { Bulgaria }\end{array}$ & $4.49 \mathrm{~m}$ & Visit Sofia & http://visitsofia.bg/en/ \\
\hline
\end{tabular}

The content of each DMO website was searched using the keywords in table 1, below. A system of keywords was used to categorise the data that refers to themes and concepts of relevance to this research that have been developed in the preceding sections on dark tourism and urban tourism. This is a deductive method of code generation (Berg 2007), that formed a starting point for an inductive process of further categorising the data to allow for the emergence of additional information of relevance to the research.

The Keywords were chosen because they are most often used in the literature when referring to the concept of dark tourism. For example, in their ground-breaking work Lennon \& Foley make use of all ten key words in describing and framing dark tourism experiences. Similarly, Stone makes use of several (especially "dark", "macabre", "tragedy" and "suffering" repeatedly in his assessment of the topic $(2005,2006)$. These works have, to a 
large extent, provided the framework for much of the study that has come in recent years, including this paper.

It is not to be assumed that the study of death related tourism is necessarily a grim one. Far from it; indeed, Stone (2013 p 1) says "...the study of dark tourism is not simply a fascination with death or the macabre, but a multi-disciplinary academic lens through which to scrutinise fundamental interrelationships of the contemporary commodification of death with the cultural condition of society". Therefore, any number of key words could have been chosen, but the fundamental importance is that they reflect the essence of what dark tourism is perceived as offering, namely, "the act of travel to sites associated with death, suffering and the seemingly macabre" (Stone 2006, p 146.)

A quick overview of key word citations in the literature which has sought to explore the topic shows that there is a consensus that dark tourism is widely regarded as being generated by an interest in sites of death (in various forms, for example from actual sites of death to cemetery visitation), which often have historical or commemorative aspects in some way.

Table 2 - Codes used for content analysis

\begin{tabular}{|l|l|}
\hline Keyword & Source \\
\hline Dark & Lennon \& Foley (2000) \\
& Stone (2006) \\
& Walter (2009) \\
& Seaton (1996) \\
& Dale \& Robinson (2011) \\
& Sharpley \&Stone (2009) \\
\hline Death & Lennon \& Foley (2000) \\
& Stone (2006) \\
\hline
\end{tabular}




\begin{tabular}{|c|c|}
\hline & $\begin{array}{l}\text { Walter (2009) } \\
\text { Seaton (1996) } \\
\text { Dale \& Robinson (2011) } \\
\text { Sharpley \&Stone (2009) }\end{array}$ \\
\hline Tragedy & $\begin{array}{l}\text { Lennon \& Foley (2000) } \\
\text { Stone (2006) } \\
\text { Walter (2009) } \\
\text { Dale \& Robinson (2011) } \\
\text { Sharpley \&Stone (2009) }\end{array}$ \\
\hline Suffering & $\begin{array}{l}\text { Lennon \& Foley (2000) } \\
\text { Stone (2006) } \\
\text { Walter (2009) } \\
\text { Dale \& Robinson (2011) } \\
\text { Sharpley \&Stone (2009) }\end{array}$ \\
\hline War & $\begin{array}{l}\text { Lennon \& Foley (2000) } \\
\text { Walter (2009) } \\
\text { Smith (1998) } \\
\text { Dale \& Robinson (2011) } \\
\text { Sharpley \&Stone (2009) }\end{array}$ \\
\hline Disaster & $\begin{array}{l}\text { Lennon \& Foley (2000) } \\
\text { Walter (2009) } \\
\text { Dale \& Robinson (2011) } \\
\text { Sharpley \&Stone (2009) }\end{array}$ \\
\hline
\end{tabular}




\begin{tabular}{|c|c|}
\hline Macabre & $\begin{array}{l}\text { Lennon \& Foley (2000) } \\
\text { Dale \& Robinson (2011) } \\
\text { Sharpley \&Stone (2009) }\end{array}$ \\
\hline $\begin{array}{l}\text { Historica } \\
\text { I }\end{array}$ & $\begin{array}{l}\text { Lennon \& Foley (2000) } \\
\text { Strange \& Kempa (2003) } \\
\text { Seaton (1996) } \\
\text { Smith (1998) } \\
\text { Dale \& Robinson (2011) } \\
\text { Sharpley \&Stone (2009) }\end{array}$ \\
\hline $\begin{array}{l}\text { Comme } \\
\text { moratio } \\
n\end{array}$ & $\begin{array}{l}\text { Lennon \& Foley (2000) } \\
\text { Walter (2009) } \\
\text { Dale \& Robinson (2011) } \\
\text { Sharpley \&Stone (2009) }\end{array}$ \\
\hline $\begin{array}{l}\text { Holocaus } \\
\text { t }\end{array}$ & $\begin{array}{l}\text { Lennon \& Foley (2000) } \\
\text { Walter (2009) } \\
\text { Dale \& Robinson (2011) } \\
\text { Sharpley \&Stone (2009) }\end{array}$ \\
\hline
\end{tabular}

The data presented by the documents collected according to the categories set out in table three was coded and sorted to allow the construction of descriptive statistics about the data. Thematic patterns and clusters of information and meaning were also be identified and reported on. This process of analysis will follow the steps set out by Creswell (2009) of first producing a detailed description the data and secondly making an interpretation of the data. 


\section{Findings}

The tables below show the results of the content analysis that was carried out of the European DMO websites outlined in table 2 , above.

From the application and analysis of the keywords used to identify themes of interest, it is clear that each of the cities studied engages in some elements of what might be classed as "dark tourism".

It was noticeable that the key word which brought the most response was "historical". This reflects the fact that often dark tourism is very closely linked to heritage and history, particularly when the host city has a well-established tourism infrastructure (London, Paris and Prague, for example) coupled with a well-defined heritage sector.

The most significant likelihood of any of the key words producing a "hit" was in the context of museums, galleries and theatres. These three attractions account for the bulk of hits across all keyword categories. It was also noticeable that a number of accommodation options were keen to emphasise their historical qualities in order to encourage bookings.

However, there were a broad range of attractions across the continuum (Stone, 2006), including torture museums, for example, designed to vicariously thrill rather than be a serious study of the topic, and some more serious attempts at commemoration for wars and the holocaust.

Table 3 - dark frequency table for London

\begin{tabular}{|l|l|}
\hline Key Word & Frequency \\
\hline Dark & 172 \\
\hline Death & 76 \\
\hline Tragedy & 20 \\
\hline Suffering & 13 \\
\hline War & 219 \\
\hline Disaster & 5 \\
\hline Macabre & 5 \\
\hline Historical & 661 \\
\hline Commemoration & 31 \\
\hline Holocaust & 9 \\
\hline Total & 1211 \\
\hline
\end{tabular}

London is the most visited city in the world. It offers a range of attractions of all sorts to visitors and tourists. Its "dark" offerings are surprisingly inauthentic (Powell \& lankova, 
2015) considering its rich and long history. It does, however, have a focus on heritage and history and there are many museums which may be considered as having some elements of dark interest. Commemoration, remembrance and historicity form the main dark components. A significant "hits" in the web search related to theatrical shows and artistic exhibitions in particular.

Table 4 - Dark frequency table for Paris

\begin{tabular}{|l|l|}
\hline Key Word & Frequency \\
\hline Dark & 43 \\
\hline Death & 38 \\
\hline Tragedy & 3 \\
\hline Suffering & 11 \\
\hline War & 67 \\
\hline Disaster & 0 \\
\hline Macabre & 0 \\
\hline Historical & 370 \\
\hline Commemoration & 11 \\
\hline Holocaust & 0 \\
\hline Total & 543 \\
\hline
\end{tabular}

Paris has many dark attractions, although often not developed as such. A large part of its revolutionary history, for example, has been expunged to some degree, meaning actual sites of historic interest are often commemorated with a plaque and little else. The city's Catholic past also means sites like the catacombs and an ossuary, for example, remain historical relics rather than an attempt to create dark attractions per se.

Table 5 - Dark frequency table for Rome

\begin{tabular}{|l|l|}
\hline Key Word & Frequency \\
\hline Dark & 8 \\
\hline Death & 17 \\
\hline Tragedy & 0 \\
\hline Suffering & 2 \\
\hline War & 180 \\
\hline
\end{tabular}




\begin{tabular}{|l|l|}
\hline Disaster & 1 \\
\hline Macabre & 1 \\
\hline Historical & 47 \\
\hline Commemoration & 2 \\
\hline Holocaust & 1 \\
\hline Total & 259 \\
\hline
\end{tabular}

Rome sees no real benefit in advertising itself as a dark city. It believes its ancient and classical past is sufficiently well known not to need the additional pull of dark fascination. Many of its sites of death (the Coliseum, for example) are mentioned in a very matter of fact way and without sensationalism.

Table 6 - Dark frequency table for Prague

\begin{tabular}{|l|l|}
\hline Key Word & Frequency \\
\hline Dark & 127 \\
\hline Death & 39 \\
\hline Tragedy & 4 \\
\hline Suffering & 5 \\
\hline War & 99 \\
\hline Disaster & 0 \\
\hline Macabre & 0 \\
\hline Historical & 248 \\
\hline Commemoration & 2 \\
\hline Holocaust & 5 \\
\hline Total & 529 \\
\hline
\end{tabular}

Prague is probably the darkest city of all those in the sample. It has the most extensive variety of truly dark sites, both actual and inauthentic, most of which are developed for tourism in some way. It covers the whole range of Stones' (2006) typology, and has attractions from the lightest to the darkest. 
Table 7 - Dark frequency table for Milan

\begin{tabular}{|l|l|}
\hline Key Word & Frequency \\
\hline Dark & 0 \\
\hline Death & 1 \\
\hline Tragedy & 0 \\
\hline Suffering & 0 \\
\hline War & 6 \\
\hline Disaster & 0 \\
\hline Macabre & 0 \\
\hline Historical & 1 \\
\hline Commemoration & 0 \\
\hline Holocaust & 0 \\
\hline Total & 8 \\
\hline
\end{tabular}

Milan has very few attractions which might be considered dark. The hits reflected in this table are due to the existence of a museum, rather than specific sites which have dark themes.

Table 8 - Dark frequency table for Barcelona

\begin{tabular}{|l|l|}
\hline Key Word & Frequency \\
\hline Dark & 4 \\
\hline Death & 11 \\
\hline Tragedy & 0 \\
\hline Suffering & 1 \\
\hline War & 71 \\
\hline Disaster & 0 \\
\hline Macabre & 0 \\
\hline Historical & 1 \\
\hline Commemoration & 0 \\
\hline Holocaust & 0 \\
\hline Total & 88 \\
\hline
\end{tabular}


Barcelona has a number of sites related to the civil war of the 1930's, and in particular a number of artistic and musical events which recall the war.

Table 9 - Dark frequency table for Amsterdam

\begin{tabular}{|l|l|}
\hline Key Word & Frequency \\
\hline Dark & 47 \\
\hline Death & 9 \\
\hline Tragedy & 1 \\
\hline Suffering & 0 \\
\hline War & 45 \\
\hline Disaster & 1 \\
\hline Macabre & 0 \\
\hline Historical & 1103 \\
\hline Commemoration & 1 \\
\hline Holocaust & 3 \\
\hline Total & 1210 \\
\hline & \\
\hline
\end{tabular}

Amsterdam is a city which is used to attracting tourists, and dark themes often presented in a way which looks to exploit their touristic value; it has a Torture Museum, for example, designed to entertain. There is an argument that the sex trade may in itself constitute a dark theme, and in that sense Amsterdam is positioned well to further develop such aspects. The very high hits generated by the word "historical" is largely explained by the very large number of hotels in particular which were keen to establish links with the past in an effort to appeal to tourists who it must be assumed are visiting for a diverse range of reasons.

Table 10 - Dark frequency table for Vienna

\begin{tabular}{|l|l|}
\hline Key Word & Frequency \\
\hline Dark & 35 \\
\hline Death & 65 \\
\hline Tragedy & 7 \\
\hline Suffering & 14 \\
\hline War & 120 \\
\hline
\end{tabular}




\begin{tabular}{|l|l|}
\hline Disaster & 10 \\
\hline Macabre & 3 \\
\hline Historical & 155 \\
\hline Commemoration & 10 \\
\hline Holocaust & 3 \\
\hline Total & 422 \\
\hline
\end{tabular}

Vienna acknowledges its past, particularly in relation to WW2, but it is keen to emphasise the more cultural and musical aspects of its history and heritage. A number of hits were related to musical and theatrical offerings not linked to real dark events. However. The Holocaust is commemorated sensitively and in a way which is accessible to tourists.

Table 11 - Dark frequency table for Venice

\begin{tabular}{|l|l|}
\hline Key Word & Frequency \\
\hline Dark & 11 \\
\hline Death & 0 \\
\hline Tragedy & 0 \\
\hline Suffering & 0 \\
\hline War & 4 \\
\hline Disaster & 0 \\
\hline Macabre & 0 \\
\hline Historical & 0 \\
\hline Commemoration & 0 \\
\hline Holocaust & 0 \\
\hline Total & 15 \\
\hline
\end{tabular}

Venice does not seek to attract tourists by employing "dark" themes. This may well be due to the fact that it emphasises other aspects of its location and heritage, possibly because it is these aspects which are proving remarkably good at attracting sufficient tourists, and if anything the city is seeking ways to reduce the sheer number of day visitors.

Table 12 - Dark frequency table for Sofia

\begin{tabular}{|l|l|}
\hline Key Word & Frequency \\
\hline
\end{tabular}




\begin{tabular}{|l|l|}
\hline Dark & 6 \\
\hline Death & 5 \\
\hline Tragedy & 0 \\
\hline Suffering & 0 \\
\hline War & 33 \\
\hline Disaster & 0 \\
\hline Macabre & 0 \\
\hline Historical & 10 \\
\hline Commemoration & 0 \\
\hline Holocaust & 0 \\
\hline Total & 54 \\
\hline
\end{tabular}

Sofia is only really just developing its outward looking tourist appeal. There are a number of soviet era monuments which commemorate WW2, and a number of museums which may be considered in that category. However, its relatively high ranking when using a key word search can be explained by the fact that, for example when searching for "war" the search engine will return words which include those letters as a sequence, as in "aWARness", for example.

\section{Conclusions}

All of the cities considered are aware of "dark tourism" as a searchable theme, although some are less concerned about the exploitation of dark themes than others or regard other aspects of their tourism offerings to be pre-eminent.

A preliminary ranking of those cities which offer the most "dark" themed results, when adjusted to discount those hits which were not within the scope of Stone's 2006 typology would be:

\begin{tabular}{|rl|}
\hline 1. & Prague \\
\hline 2. & London \\
\hline 3. & Paris \\
\hline 4. & Amsterdam \\
\hline 5. & Barcelona \\
\hline 6. & Rome \\
\hline
\end{tabular}




\begin{tabular}{|c|}
\hline 7. Vienna \\
\hline 8. Sofia \\
\hline 9. Venice \\
\hline 10. Milan \\
\hline
\end{tabular}

Table 13 ranking of cities on a subjective perception of dark themes

It should be noted that Stone's continuum shows dark attractions ranging from the very darkest to the lightest. It is important to remember, therefore, that to be "dark" does not necessarily mean a city would need to position itself at either end of the scale to successfully attract tourists. Indeed, the top five in table 13 demonstrate that successful marketing based on perceptions of darkness involves the development of a tourism infrastructure which can exploit a variety of opportunities. Of course, it should also be remembered that different attractions on the continuum require different approaches, bearing in mind the commercial exploitation of the darkest sites is controversial to say the least.

This paper, therefore, sought to identify the extent to which dark tourism is a significant factor (or otherwise) in the development of urban tourism in a European context. Having established that dark tourism is a factor in the touristic offering of the most visited cities, albeit more so in some than others, the authors' intentions are to further develop this research in a way which more accurately maps the dark tourism offer and to examine its potential to further develop urban tourism by developing an integrated network of European "dark" cities, seeking to unite a clearly established motivating factor (demand) to ways in which that demand can be satisfied (supply). 


\section{References}

Berg, B. (2007) Qualitative Research Methods for the Social Sciences, London: Sage

Bryman, A. \& Bell, E. (2007) Business Research Methods, Oxford: Oxford University Press

Dale, C., \& Robinson, N. (2011), "Dark Tourism”, in Robinson, P., Heitmann, S., \& Dieke, P. (Eds). Research Themes for Tourism, 38(1), pp 193-209.

Euromonitor (2014) Top 100 City Destinations Ranking [online]

Available from: http://blog.euromonitor.com/2014/01/euromonitor-internationals-top-citydestinations-ranking.html

Accessed 10/05/2015

Gale, T. (2005) 'Modernism, Post-modernism and the Decline of British Seaside Resorts as Long Holiday Destinations: A Case Study of Rhyl, North Wales' in Tourism Geographies, Vol. 7, No.1, pp.86-112

Hoffman, L. (2003) 'The Marketing of Diversity in the Inner City: Tourism and Regulation in Harlem' in International Journal of Urban and Regional Research, Vol.27, No.2, pp.286-99

Lennon, J., \& Foley, M. (2000). Dark Tourism: the attraction of death and disaster, Thomson, London.

Powell, R., and lankova, K. (2015) Dark London: Dimensions and characteristics of dark tourism supply in the UK capital. Anatolia: An International Journal of Tourism and Hospitality Research. ISSN 1303-2917 (Print), 2156-6909 (Online) (In Press) 
Richards, G. (ed.) (2007) Cultural Tourism: Global and Local Perspectives, New York: Haworth Press

Richards, G. \& Wilson, J. (2007) 'The Creative Turn in Regeneration: Creative Spaces, Spectacles and Tourism in Cities' in Smith, M. (ed.) Tourism Culture and Regeneration, Wallingford: $\mathrm{CABI}$, pp. 12-24

Seaton, A.V. (1996). "Guided by the dark: from thanatopsis to thanatourism", International Journal of Heritage Studies, 2(4), pp.234-244.

Selby, M. (2004) Understanding Urban Tourism, London: IB Tauris

Sharpley, R. and Stone, P. (2009), The Darker Side of Travel: The Theory and Practice of Dark Tourism, Channel View Publications, Bristol.

Smith, M. (2007) 'Space, Place and Placelessness in the Culturally Regenerated City' in Richards, G. (ed.) Cultural Tourism: Global and Local Perspectives, New York: Haworth Press, pp. $91-108$

Smith, V. (1998). "War and tourism: an American ethnography". Annals of Tourism Research, 25, 202-227

Spirou, C. (2007) 'Cultural Policy and Urban Restructuring in Chicago' in Smith, M. (ed.) Tourism Culture and Regeneration, Wallingford: CABI, pp. 123-131

Stone, P. (2006). "A Dark Tourism spectrum: towards a typology of death and macabre related tourist sites, attractions and exhibitions", Tourism ,54(2), pp. 145-160 
Stone, P. (2005), "Review: Dark Tourism - cashing in on tragedy?", paper presented at the Tourism Society Seminar Event, 17 October, London, available at: www.dark-tourism.org.uk (accessed 06 September 2013)

Stone, P. (2013). Dark tourism scholarship: a critical review. International Journal of Culture, Tourism and Hospitality Research, 7(3), 307-318.

Strange, C., \& Kempa, M. (2003). "Shades of Dark Tourism: Alcatraz and Robben Island" Annals of Tourism Research, 30(2) pp.386-405.

Tarlow, P. (2005). Dark tourism: The appealing 'dark'side of tourism and more. Niche tourism: Contemporary issues, trends and cases, 47-57.

Urry, J. (2002) The Tourist Gaze $2^{\text {nd }}$ ed., London: Sage

Van den Berg, L., J. van der Borg and J. van der Meer (1995), Urban Tourism; Performance and strategies in eight European cities, Euricur Series, Ashgate, Aldershot

Vellas, F. \& Becherel, L. (1995), International Tourism, Belhaven, London.

Walter, T. (2009), “Disaster, modernity, and the media” in Garces-Foley, K. (Ed), Death and Religion in a Changing World, M.E. Sharpe, Armonk, NY.

Zukin, S. (1995) The Cultures of Cities, Oxford: Blackwell 